\title{
Optimization of sonochemical degradation of tetracycline in aqueous solution using sono-activated persulfate process
}

\author{
Gholam Hossein Safari ${ }^{1}$, Simin Nasseri ${ }^{1,2^{*}}$, Amir Hossein Mahvi ${ }^{1,3}$, Kamyar Yaghmaeian ${ }^{1,3}$, Ramin Nabizadeh ${ }^{1,4}$
} and Mahmood Alimohammadi ${ }^{1}$

\begin{abstract}
Background: In this study, a central composite design (CCD) was used for modeling and optimizing the operation parameters such as $\mathrm{pH}$, initial tetracycline and persulfate concentration and reaction time on the tetracycline degradation using sono-activated persulfate process. The effect of temperature, degradation kinetics and mineralization, were also investigated.

Results: The results from CCD indicated that a quadratic model was appropriate to fit the experimental data $(p<0.0001)$ and maximum degradation of $95.01 \%$ was predicted at $\mathrm{pH}=10$, persulfate concentration $=4 \mathrm{mM}$, initial tetracycline concentration $=30.05 \mathrm{mg} / \mathrm{L}$, and reaction time $=119.99 \mathrm{~min}$. Analysis of response surface plots revealed a significant positive effect of $\mathrm{pH}$, persulfate concentration and reaction time, a negative effect of tetracycline concentration. The degradation process followed the pseudo-first-order kinetic. The activation energy value of $32.01 \mathrm{~kJ} / \mathrm{mol}$ was obtained for $\mathrm{US} / \mathrm{S}_{2} \mathrm{O}_{8}^{2-}$ process. Under the optimum condition, the removal efficiency of COD and TOC reached to $72.8 \%$ and $59.7 \%$, respectively. The changes of UV-Vis spectra during the process was investigated. The possible degradation pathway of tetracycline based on loses of N-methyl, hydroxyl, and amino groups was proposed.
\end{abstract}

Conclusions: This study indicated that sono-activated persulfate process was found to be a promising method for the degradation of tetracycline.

Keywords: Tetracycline degradation, Persulfate, Response surface methodology, Central composite design, Optimization

\section{Background}

Tetracycline (TC) is extensively used for the prevention and treatment of infectious diseases in human and veterinary medicine and as feed additives for promote growth in agriculture $[1,2]$. Because of their extensive usage, their strongly hydrophilic feature, low volatility [2] and relatively long half-life [3], TC antibiotic has been frequently detected in different environmental matrices: surface waters $(0.07-1.34 \mu \mathrm{g} / \mathrm{L})[4]$, soils $(86.2-198.7 \mu \mathrm{g} /$ $\mathrm{kg})$ [5], liquid manures $(0.05-5.36 \mu \mathrm{g} / \mathrm{kg})$ [5] and in $90 \%$ of farm lagoon samples $(>3 \mu \mathrm{g} / \mathrm{L})$ [6]. In addition to environmental contamination, the occurrence of $\mathrm{TC}$ in

\footnotetext{
* Correspondence: naserise@tums.ac.ir

'Department of Environmental Health Engineering, School of Public Health,

Tehran University of Medical Sciences, Tehran, Iran

${ }^{2}$ Center for Water Quality Research, Institute for Environmental Research,

Tehran University of Medical Sciences, Tehran, Iran

Full list of author information is available at the end of the article
}

the aquatic environments would also increase antibiotic resistance genes [7]. However, due to the antibacterial nature of TC, they cannot effectively be removed by conventional biological processes [8]. In wastewater treatment plants, the TC removal efficiency varied in the range of $12 \%$ to $80 \%[9,10]$. For example, concentrations of TC residues have been detected in values of 0.97 to $2.37 \mu \mathrm{g} / \mathrm{L}$ in the final effluent from wastewater treatment plants [11]. Hence, the effort to develop new processes to minimize the tetracycline residues discharges into the environment is become essential. Physicochemical processes such as membrane filtration and adsorption using activated carbon have been used to removal of TC. These processes are not efficient enough, transfer the pollutant from one phase to another [12, 13]. Advanced oxidation processes (AOPs) such as $\left(\mathrm{O}_{3} / \mathrm{H}_{2} \mathrm{O}_{2}\right.$, $\mathrm{US} / \mathrm{O}_{3}, \mathrm{UV} / \mathrm{O}_{3}, \mathrm{UV} / \mathrm{H}_{2} \mathrm{O}_{2}, \mathrm{H}_{2} \mathrm{O}_{2} / \mathrm{Fe}^{2+}$, US-TiO ${ }_{2}$ and 
UV- $\mathrm{TiO}_{2}$ ) have been proposed as very effective alternatives to degrade tetracycline antibiotics. The primary of AOPs is production of hydroxyl radical in water, a much powerful oxidant in the degradation of a wide range of organic pollutants [12-15]. Recently, the application of sulfate radical-based advanced oxidation processes (SR-AOPs) to oxidation of biorefractory organics have attracted great interest $[16,17]$. Persulfate (PS, $\mathrm{S}_{2} \mathrm{O}_{8}^{2-}$ ) is a powerful and stable oxidizing agent $\left(\mathrm{E}_{0}=2.01 \mathrm{~V}\right.$ vs. NHE), which has high aqueous solubility and high stability at room temperature as compared to hydrogen peroxide $\left(\mathrm{H}_{2} \mathrm{O}_{2}, \mathrm{E}_{0}=1.77 \mathrm{~V}\right.$ vs. NHE) $[18,19]$.

Sulfate radicles could be produced through the activation of persulfate (PS, $\mathrm{S}_{2} \mathrm{O}_{8}^{2-}$ ) with ultraviolet [20], heat $[21,22]$, microwave [23], sonolysis [24], base [25], granular activated carbon [26], quinones [27], phenols [28], soil minerals [29], radiolysis [30] and transition metals $[31,32]$. Sulfate radicals are more effective than hydroxyl radical in the oxidation of organic contaminants. They have higher redox potentials, longer half-life and higher selectivity in the oxidation of organic contaminants $\left(\mathrm{SO}_{4}^{-}\right.$ -, $\mathrm{E}_{0}=2.5-3.1$, half-life $\left.=30-40 \mu \mathrm{s}\right)$ than hydroxyl radical $\left(\mathrm{HO}^{*}, \mathrm{E}_{0}=1.89-2.72 \mathrm{~V}\right.$, half-life $\left.=10^{-3} \mu \mathrm{s}\right)$ [33-39]. Hence, the organic pollutants could be oxidized entirely by $\mathrm{SO}_{4}^{-*}$, especially benzene derivatives compounds [18]. Generally, sulfate radical reacts with organic contaminants predominantly through selective electron transfer, while hydroxyl radical mainly reacts through hydrogen abstraction and addition. Therefore, the possibility of sulfate radical scavenging by nontarget compounds is lower than hydroxyl radical [39-42].

Sonochemical treatment is an emerging and efficient process that applied pyrolytic cleavages to degradation of organic compounds [42, 43]. This process is a cleaner and safe technique compared with UV, ozonation, and has the ability of operation under ambient conditions [43, 44]. However, combination of ultrasound with various processes has been detected as an economical and successful alternative for the degradation and mineralization of some recalcitrant organic compounds in aqueous solution [42]. The combination of ultrasound and persulfate $\left(\mathrm{US} / \mathrm{S}_{2} \mathrm{O}_{8}^{2-}\right.$ ) has been effective for the degradation of compounds such as; methyl tert-butyl ether (MTBE) [45], nitric oxide [18], 1,4-dioxane [46], arsenic(III) [44], amoxicillin [47], tetracycline [48] and dinitrotoluenes [24]. In aqueous solutions, acoustic cavitation leading to produce plasma in water and free radicals and other reactive species such as $\mathrm{HO}^{*}$ and $\mathrm{H}^{*}$ radicals due to the thermal degradation of water according to Reaction (1) and (2). The $\mathrm{HO}^{*}$ and $\mathrm{H}^{*}$ radicals can also react with PS to production of more reactive $\mathrm{SO}_{4}^{-*}$ radicals according to Reactions (3) to (7) [42, 44, 49, 50].

$$
\begin{aligned}
& \mathrm{H}_{2} \mathrm{O} \stackrel{()))}{\rightarrow} \mathrm{H}_{2} \mathrm{O} \text { plasma } \\
& \mathrm{H}_{2} \mathrm{O} \stackrel{()))}{\rightarrow} \mathrm{HO}^{\bullet}+\mathrm{H}^{\bullet}
\end{aligned}
$$

Where "))))))" refers to ultrasonication. In the presence of $\mathrm{S}_{2} \mathrm{O}_{8}^{2-}$ :

$$
\begin{aligned}
& \mathrm{S}_{2} \mathrm{O}_{8}^{-2}+\stackrel{()))}{\rightarrow} 2 \mathrm{SO}_{4}^{-\cdot} \\
& \mathrm{SO}_{4}^{-\cdot}+\mathrm{H}_{2} \mathrm{O} \rightarrow \mathrm{SO}_{4}^{2-}+\mathrm{HO}^{\cdot}+\mathrm{H}^{+} \\
& \mathrm{S}_{2} \mathrm{O}_{8}^{-2}+\mathrm{HO} \rightarrow \mathrm{HSO}_{4}^{-}+\mathrm{SO}_{4}^{-\cdot}+\frac{1}{2} \mathrm{O}_{2} \\
& \mathrm{~S}_{2} \mathrm{O}_{8}^{-2}+\mathrm{H}^{\cdot} \rightarrow \mathrm{HSO}_{4}^{-}+\mathrm{SO}_{4}^{-\cdot} \\
& \mathrm{S}_{2} \mathrm{O}_{8}^{-2}+\stackrel{\text { pyrolysis }}{\rightarrow} 2 \mathrm{SO}_{4}^{-\cdot}
\end{aligned}
$$

In aqueous solution, Hydroxyl radicals may be produced via the degradation of persulfate and/or ultrasonic irradiation. Ultrasonic irradiation could also lead to cavitation through the formation, growth and collapse of tiny gas bubbles in the water [51]. Moreover, during US irradiation, the collapse of cavitation bubbles leads to higher temperatures and pressures that produces free radicals and other reactive species and would also increase the number of collisions between free radicals and contaminants [42, 44, 49,50].

The specific objectives of this study were to optimize the TC degradation in aqueous solution using $\mathrm{US} / \mathrm{S}_{2} \mathrm{O}_{8}^{2-}$ process. Response surface methodology (RSM) is a reliable statistical technique for developing, improving and optimizing processes and can be used to assess the relative significance of several affecting factors with the least experiments [52-54]. Therefore, an experimental design methodology using RSM and CCD was used to evaluate the effect of operational parameters such as initial TC concentration, initial $\mathrm{S}_{2} \mathrm{O}_{8}^{2-}$ concentration, initial $\mathrm{pH}$ and reaction time on the sonochemical degradation of tetracycline. In addition, the effect of temperature, degradation kinetics, mineralization, changes of ultraviolet Visible (UV-Vis) spectra and the proposed degradation pathway of $\mathrm{TC}$ by the $\mathrm{US} / \mathrm{S}_{2} \mathrm{O}_{8}^{2-}$ process were investigated. This study as part of a $\mathrm{PhD}$ dissertation of the first author was performed at Department of Environmental Health Engineering, School of Public Health, Tehran University of Medical Sciences in 2015.

\section{Materials and methods}

\section{Materials}

Tetracycline hydrochloride $\left[\mathrm{C}_{22} \mathrm{H}_{25} \mathrm{~N}_{2} \mathrm{O}_{8} \mathrm{Cl}\right]$ (AR, $99 \%$ ), was provided from Sigma-Aldrich. Chemical properties of tetracycline hydrochloride are shown in Table 1 [2]. Sodium persulfate $\left(\mathrm{Na}_{2} \mathrm{~S}_{2} \mathrm{O}_{8}, 98 \%\right)$ was provided from Sigma-Aldrich. All other chemicals were of analytical 
Table 1 Chemical properties of tetracycline hydrochloride

\begin{tabular}{llccccc}
\hline Molecule & Formula & Molecular weight $(\mathrm{g} / \mathrm{mol})$ & Solubility $(\mathrm{mol} / \mathrm{L})$ & $\mathrm{pK}_{\mathrm{a} 1}$ & $\mathrm{pK}_{\mathrm{a} 2}$ & $\mathrm{pK} \mathrm{a}_{3}$ \\
\hline $\mathrm{TC}$ & $\mathrm{C}_{22} \mathrm{H}_{24} \mathrm{O}_{8} \mathrm{~N}_{2} \cdot \mathrm{HCl}$ & 480.9 & 0.041 & $3.2 \pm 0.3$ & $7.78 \pm 0.05$ & $9.6 \pm 0.3$ \\
\hline
\end{tabular}

grade and were used without further purification. The water used in all experiments was purified by a Milli- Q system.

\section{Procedure}

Schematics of the experimental setup applied in this study is demonstrated in Fig. 1. A stock solution of tetracycline was daily prepared with distilled deionized water and diluted as required initial concentration. Sonochemical treatment was carried out with a fixed volume of $100 \mathrm{~mL}$ of TC solution in a glass vessel of $200 \mathrm{~mL}$. The vessel was wrapped with tinfoil in order to avoid any photochemical effects. The $\mathrm{pH}$ adjustments were conducted with $1 \mathrm{~m} \mathrm{NaOH}$ or $1 \mathrm{~m} \mathrm{HCL}$ (Merck Co.) using a $\mathrm{pH}$ meter (E520, Metrohm, Tehran, Iran). Sonochemical treatment was performed with an ultrasonic generator at a frequency of $35 \mathrm{kHz}$ and power of 500 W (Elma, Singen, Germany). The reactor was immersed into the ultrasonic bath and its location was always kept similarly. All experiments were conducted at constant temperature using cooling water and temperature controller. At pre-specified time intervals, $2 \mathrm{~mL}$ sample was withdrawn, filtered through $0.22 \mu \mathrm{m}$ syringe filter and mixed with the same volume of methanol to quench the reaction before analysis [3].

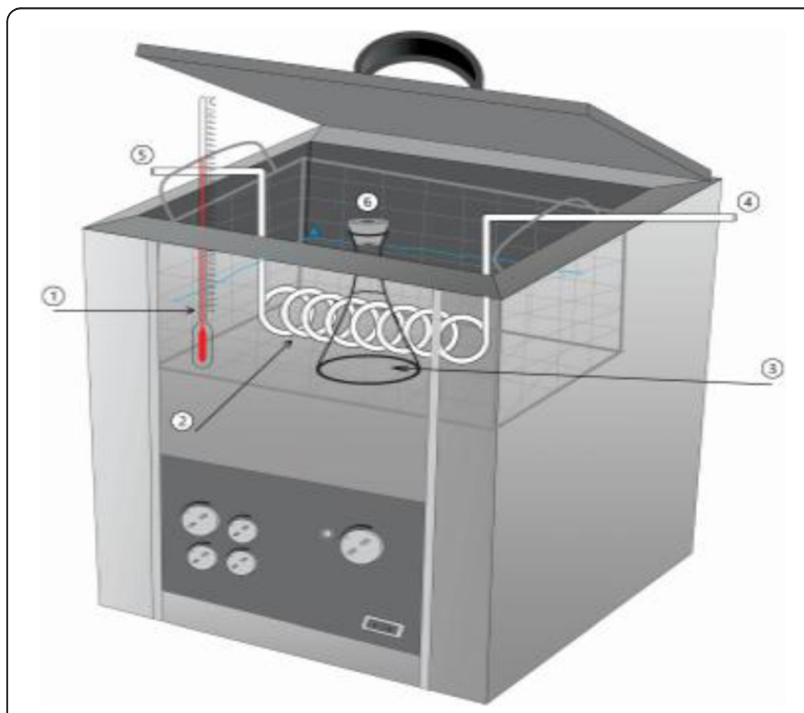

Fig 1 Schematic of the experimental used in this study; (1) temperature controller, (2) water-circulating (3) TC solution reactor (4) cooling water inlet, (5) cooling water outlet (6) sampling port

\section{Analytical methodology}

The $\mathrm{pH}$ was determined at room temperature using an $\mathrm{S}-20 \mathrm{pH}$ meter, which was calibrated with $\mathrm{pH} 4.0$ and 7 reference buffer solutions. The concentration of $\mathrm{TC}$ in aqueous solution was analyzed by HPLC, with a LC-20 AB pump, Shimadzu, Kyoto, Japan) with a reversedphase column (VP-ODS-C18 $4.6 \mathrm{~mm} \times 250 \mathrm{~mm}, 5 \mu \mathrm{m}$, Shim-Pack, Kyoto, Japan), and UV detector (Shimadzu UV-1600 spectrophotometer). The injection volume was $20 \mu \mathrm{L}$; the mobile phase was acetonitrile $0.01 \mathrm{M}$, oxalic acid solution $(31: 69, \mathrm{v} / \mathrm{v})$ with a flow rate of $1.0 \mathrm{~mL} \mathrm{~min}$

${ }^{-1}$. The detection wavelength and retention time of tetracycline were $360 \mathrm{~nm}$ and $2.38 \mathrm{~min}$, respectively. In this study, limit of detection (LOD) were found to be 0.02 $0.03 \mathrm{mg} / \mathrm{L}$ based on linear regression method.

\section{Experimental design}

A central composite statistical experiment design was used to evaluate the effects of four independent variables (initial solution $\mathrm{pH}(\mathrm{A})$, initial TC concentration (B), initial $\mathrm{S}_{2} \mathrm{O}_{8}^{-2}$ concentration $(\mathrm{C})$ and reaction time (D)) on the TC degradation. The application of RSM provides a mathematical relationship between variables and experimental data can be fitted to an empirical second-order polynomial model as the following Eq. (8). [55-57].

$$
\begin{aligned}
Y= & \beta_{0}+\beta_{1} A+\beta_{2} B+\beta_{3} C+\beta_{4} D+\beta_{12} A B \\
& +\beta_{13} A C+\beta_{14} A D+\beta_{23} B C+\beta_{24} B D \\
& +\beta_{34} C D+\beta_{11} A^{2}+\beta_{22} B^{2}+\beta_{33} C^{2} \\
& +\beta_{44} D^{2}
\end{aligned}
$$

Where, y (\%) is the predicted response (TC degradation rate), $\beta_{0}$ is interception coefficient, $\beta_{1}, \beta_{2}, \beta_{3}$ and $\beta_{4}$ are the linear coefficients, $\beta_{12}, \beta_{13}, \beta_{14}, \beta_{23}, \beta_{24}$ and $\beta_{34}$ are interaction coefficients, $\beta_{11}, \beta_{22}, \beta_{33}$ and $\beta_{44}$ are the quadratic coefficients and $A, B, C$ and $D$ are the independent variables.

The natural and coded levels of independent variables based on the central composite design are shown in Table 2. The experimental values for each independent variables were chosen according to the results obtained from preliminary analysis. Table 3 indicates the fourfactor, five-level CCD and the obtained and predicted values for the TC degradation rate (\%) using the developed quadratic model. In RSM analysis, the approximation of $y$ was proposed using the fitted second-order polynomial regression model which is called the quadratic model. A quadratic regression is the process of finding the equation of the parabola that fits best for a set of data [58]. 
Table 2 Natural and coded levels of independent variables based on the central composite design

\begin{tabular}{|c|c|c|c|c|c|c|}
\hline \multirow[t]{2}{*}{ Independent variable } & \multirow[t]{2}{*}{ Symbol } & \multicolumn{5}{|c|}{ Coded levels } \\
\hline & & -2 & -1 & 0 & +1 & +2 \\
\hline & & \multicolumn{5}{|c|}{ Natural level } \\
\hline $\mathrm{pH}$ & A & 2.5 & 5 & 7.5 & 10 & 12.5 \\
\hline Tetracycline (mg/L) & B & 10 & 30 & 50 & 70 & 90 \\
\hline Persulfate (Mm) & C & 1 & 2 & 3 & 4 & 5 \\
\hline Reaction time (min) & D & 30 & 60 & 90 & 120 & 150 \\
\hline
\end{tabular}

Table 3 Four-factor five-level central composite design for RSM

\begin{tabular}{|c|c|c|c|c|c|c|}
\hline \multirow[t]{2}{*}{ Run } & \multicolumn{4}{|c|}{ Experimental conditions } & \multicolumn{2}{|c|}{ TC degradation rate (\%) } \\
\hline & $\mathrm{pH}(\mathrm{A})$ & Tetracycline (mg/L) (B) & Persulfate (mM) (C) & Time (min) (D) & Observed (\%) & Predicted (\%) \\
\hline 1 & $7.5(0)$ & $50(0)$ & $3(0)$ & $90(0)$ & 51.06 & 49.82 \\
\hline 2 & $2.5(-2)$ & $50(0)$ & $3(0)$ & $90(0)$ & 55.64 & 55.74 \\
\hline 3 & $7.5(0)$ & $50(0)$ & $3(0)$ & $90(0)$ & 48.45 & 49.82 \\
\hline 4 & $5(-1)$ & $70(+1)$ & $4(+1)$ & $60(-1)$ & 45.16 & 44.64 \\
\hline 5 & $5(-1)$ & $30(-1)$ & $4(+1)$ & $120(+1)$ & 86.62 & 86.33 \\
\hline 6 & $10(+1)$ & $70(+1)$ & $2(-1)$ & $120(+1)$ & 61.02 & 61.32 \\
\hline 7 & $7.5(0)$ & $50(0)$ & $3(0)$ & $150(+2)$ & 81.85 & 81.17 \\
\hline 8 & $5(-1)$ & $30(-1)$ & $2(-1)$ & $60(-1)$ & 34.55 & 35.25 \\
\hline 9 & $10(+1)$ & $30(-1)$ & $2(-1)$ & $60(-1)$ & 47.25 & 46.91 \\
\hline 10 & $10(+1)$ & $30(-1)$ & $4(+1)$ & $60(-1)$ & 70.44 & 69.95 \\
\hline 11 & $5(-1)$ & $30(-1)$ & $2(-1)$ & $120(+1)$ & 61.85 & 61.79 \\
\hline 12 & $7.5(0)$ & $50(0)$ & $1(-2)$ & $90(0)$ & 28.72 & 28.18 \\
\hline 13 & $10(+1)$ & $70(+1)$ & $4(+1)$ & $120(+1)$ & 85.05 & 84.34 \\
\hline 14 & $7.5(0)$ & $50(0)$ & $3(0)$ & $90(0)$ & 49.75 & 49.82 \\
\hline 15 & $10(+1)$ & $30(-1)$ & $2(-1)$ & $120(+1)$ & 75.56 & 76.07 \\
\hline 16 & $10(+1)$ & $30(-1)$ & $4(+1)$ & $120(+1)$ & 94.25 & 95.04 \\
\hline 17 & $5(-1)$ & $70(+1)$ & $2(-1)$ & $60(-1)$ & 12.65 & 11.98 \\
\hline 18 & $5(-1)$ & $30(-1)$ & $4(+1)$ & $60(-1)$ & 64.04 & 63.86 \\
\hline 19 & $7.5(0)$ & $90(+2)$ & $3(0)$ & $90(0)$ & 41.15 & 41.31 \\
\hline 20 & $10(+1)$ & $70(+1)$ & $4(+1)$ & $60(-1)$ & 54.88 & 55.05 \\
\hline 21 & $7.5(0)$ & $50(0)$ & $3(0)$ & $90(0)$ & 50.55 & 49.82 \\
\hline 22 & $7.5(0)$ & $50(0)$ & $3(0)$ & $90(0)$ & 49.75 & 49.82 \\
\hline 23 & $7.5(0)$ & $50(0)$ & $5(+2)$ & $90(0)$ & 79.38 & 79.82 \\
\hline 24 & $12.5(+2)$ & $50(0)$ & $3(0)$ & $90(0)$ & 80.62 & 80.42 \\
\hline 25 & $7.5(0)$ & $10(-2)$ & $3(0)$ & $90(0)$ & 75.55 & 75.28 \\
\hline 26 & $7.5(0)$ & $50(0)$ & $3(0)$ & $90(0)$ & 49.35 & 49.82 \\
\hline 27 & $7.5(0)$ & $50(0)$ & $3(0)$ & $30(-2)$ & 24.75 & 25.33 \\
\hline 28 & $5(-1)$ & $70(+1)$ & $2(-1)$ & $120(+1)$ & 42.25 & 42.72 \\
\hline 29 & $10(+1)$ & $70(+1)$ & $2(-1)$ & $60(-1)$ & 27.68 & 27.96 \\
\hline 30 & $5(-1)$ & $70(+1)$ & $4(+1)$ & $120(+1)$ & 70.85 & 71.31 \\
\hline
\end{tabular}

\section{Resulta and Disscusion}

Analysis of variance (ANOVA)

The results of the analysis of variance test is summarized in Table 4. The probability $>\mathrm{F}$ for the model is less than 0.05 which implies that the model is significant and the terms in the model have significant effects on the response. In this case $\mathrm{A}, \mathrm{B}, \mathrm{C}, \mathrm{D}, \mathrm{AB}, \mathrm{AC}, \mathrm{AD}, \mathrm{BC}, \mathrm{BD}$, $C D, A 2, B^{2}, C^{2}, D^{2}$ are significant model terms at the $95 \%$ confidence level ( $\alpha=5 \%)$. The model F-value of 1387.59 and $P$-value of $<0.0001$ implies that the model is highly significant. Based on the ANOVA results, the values of $R^{2}$, Adjusted $R^{2}$ and Predicted $R^{2}$ were 0.9992 , 0.9985 and 0.9971 , respectively. This result suggests that the regression model is well interpreted the relationship 
Table 4 ANOVA results for Response Surface Quadratic Model

\begin{tabular}{llllll}
\hline Source & Sum of squares & $\mathrm{df}$ & Mean square & $\mathrm{F}$-Value & $P$-value \\
\hline model & 12060.48 & 1 & 861.46 & 1387.59 & $<0.0001$ \\
A-pH & 914.15 & 1 & 914.15 & 1472.45 & $<0.0001$ \\
B-TCcon. & 1730.94 & 1 & 1730.94 & 2788.08 & $<0.0001$ \\
C-PScon. & 3999 & 1 & 3999 & 6441.32 & $<0.0001$ \\
D-Time & 4676.04 & 1 & 4676.04 & 7531.85 & $<0.0001$ \\
AB & 18.66 & 1 & 18.66 & 30.06 & $<0.0001$ \\
AC & 30.97 & 1 & 30.97 & 49.88 & $<0.0001$ \\
AD & 6.84 & 1 & 6.84 & 11.01 & 0.0047 \\
BC & 16.4 & 1 & 16.4 & 26.42 & 0.0001 \\
BD & 17.64 & 1 & 17.64 & 28.41 & $<0.0001$ \\
CD & 16.61 & 1 & 16.61 & 26.75 & 0.0001 \\
A $^{2}$ & 571.64 & 1 & 571.64 & 920.76 & $<0.0001$ \\
$B^{2}$ & 123.3 & 1 & 123.3 & 198.6 & $<0.0001$ \\
$C^{2}$ & 29.96 & 1 & 29.96 & 48.26 & $<0.0001$ \\
$D^{2}$ & 20.18 & 1 & 20.18 & 32.5 & $<0.0001$ \\
Residual & 9.31 & 15 & 0.62 & & \\
Lack of Fit & 5.13 & 10 & 0.51 & 0.61 & 0.7607 \\
Pure Error & 4.18 & 5 & 0.84 & & \\
Cor Total & 12069.8 & 29 & & & \\
\hline$R^{2}=0.9992 ; A d u s t a R^{2}=0.9985$ & & & &
\end{tabular}

$\mathrm{R}^{2}=0.9992 ;$ Adjusted $\mathrm{R}^{2}=0.9985$ and Predicted $\mathrm{R}^{2}=0.9971$

between the independent variables and the response. Furthermore, the adequate precision ratio of 149.08 in the study shows that this model could be applied to navigate the design space defined by the CCD.

\section{Evaluation of model adequacy}

There are many statistical techniques for the evaluation of model adequacy, but graphical residual analysis is the primary statistical method for assessment of model adequacy [59].

The normal probability plot indicates that the points on this plot are formed a nearly linear pattern (Fig. 2 (a)). Therefore, the normal distribution is a good model for this data set. Random scattering of the points of internally studentized residual (the residual divided by the estimated standard deviation of that residual) versus predicted values between -3 and +3 emphasizes highly accurate prediction of the experimental data through the derived quadratic model (Fig. 2 (b)).

The plot of predicted vs Actual values (Fig. 2 (c)) indicate a higher correlation and low differences between actual and predicted values. Hence, the predictions of the experimental data by developed quadratic models for the TC degradation is perfectly acceptable and this model fits the data better. Also, the random spread of the residuals across the range of the data between -3 and +3 implies that there are no evident drift in this process and the model was a goodness fit (Fig. 2 (d)). The Box-cox plot is used for determine the suitability of a power low transformation for the selected data (Fig. 3 (a)). In this study, the best lambda values of 0.92 was obtained with low and high confidence interval 0.73 and 1.11, respectively. Therefore, recommend the standard transformation by the software is 'None'. The plot of points Leverage vs Run order is shown in Fig. 3 (b). The factorial and axial points have the most influence with a leverage of approximately 0.59 , while the center points have the least effect with a leverage of 0.16 .

\section{Design matrix evaluation for response surface quadratic model}

Design matrix evaluation implies that there are no aliases for the quadratic model. In general, a minimum of degrees of freedom 3 and 4 has been recommended for lack-of-fit and pure error, respectively. Therefore, degrees of freedom obtained in this study ensured a valid lack of fit test (Table 5).

The standard error (SE) used to measure the precision of the estimate of the coefficient. The smaller standard error implies the more accurate the estimate. The variables of $\mathrm{A}, \mathrm{B}, \mathrm{C}$ and $\mathrm{D}$ have a standard errors $=0.16$. The interceptions of $\mathrm{AB}, \mathrm{AC}, \mathrm{AD}, \mathrm{BC}, \mathrm{BD}$ and $C D$ have slightly high standard errors $=0.2$, while $\mathrm{A}^{2}, \mathrm{~B}^{2}, \mathrm{C}^{2}$ and $\mathrm{D}^{2}$ have standard errors $=0.15$. An approximate $95 \%$ confidence interval for the coefficient is given by the estimate plus and minus 2 times the standard error. For example, with $95 \%$ confidence can be said that the value of the regression coefficient $\mathrm{A}$ is between 6.49 and $5.85(6.17 \pm 2 \times 0.16)$.

The quadratic model coefficients for the CCD are shown in Table 6. This results suggested that the variables coefficients and their interactions are estimated adequately without multicollinearity. The low Ri-squared for independent variables and their interactions imply that the model is a good fit. In general, power should be approximately $80 \%$ for detecting an effect [60]. In this study, there are more than $99 \%$ chance of detecting a main effect while it is twice the background sigma.

\section{Final equation and model graphs}

The values of regression coefficients were determined and the experimental results of CCD were fitted with second order polynomial equation. The quadratic model for TC degradation rate in terms of coded were determined using as following Eq. (9): 

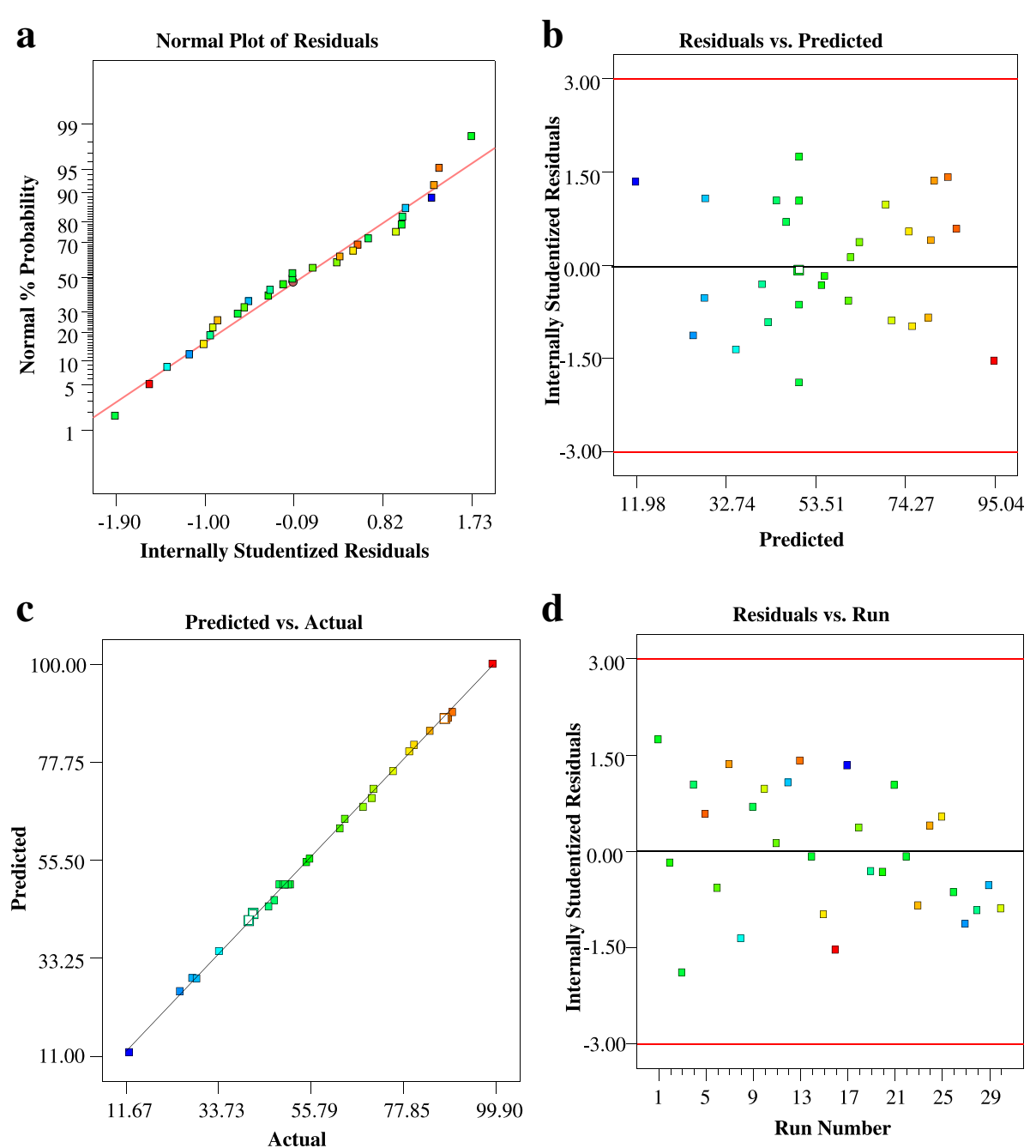

Fig 2 The plot of: (a) Normal Plot of Residuals; (b) residuals vs Predicted Response; (c) predicted vs Actual values; (d) Residuals vs Run Order
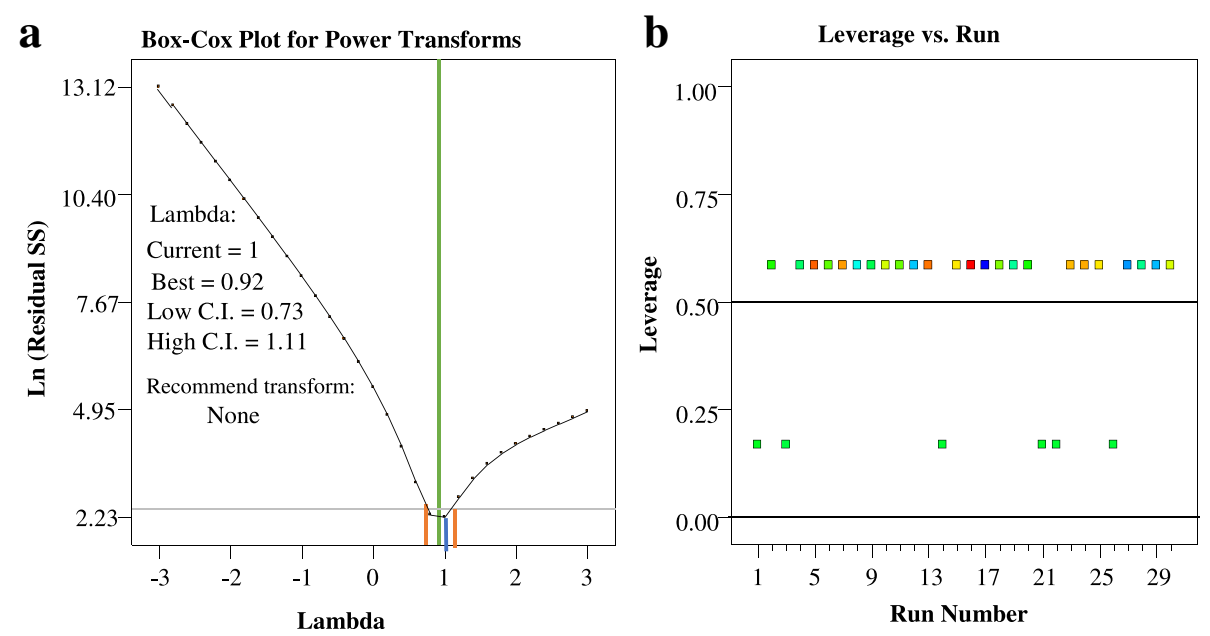

Fig 3 The plot of: (a) Box-Cox Plot for Power Transforms; (b) The points Leverage vs Run order for the CCD Design 
Table 5 Degrees of freedom for evaluation

\begin{tabular}{ll}
\hline Model & 14 \\
\hline Residuals & 15 \\
Lack of Fit & 10 \\
Pure Error & 5 \\
\hline
\end{tabular}

Final equation in terms of coded factors

$$
\begin{aligned}
Y= & +49.82+6.17 * A-8.49 * B+12.91 * C \\
& +13.96 * D+1.08 * A * B-1.39 * A * C \\
& +0.65 * A * D+1.01 * B * C+1.05 * B \\
& * D-1.02 * C * D+4.57 * A^{2}+2.12 * B^{2} \\
& +1.05 * C^{2}+0.86 * D^{2}
\end{aligned}
$$

The factors in the quadratic equation were coded to produce the response surface with limiting the responses into a range of -1 to +1 . The ramp function graph for the maximum TC degradation rate is shown in Fig. 4. The optimization of experimental conditions was conducted for maximize the TC degradation at defined criteria of the variable. The developed quadratic model for the TC degradation (Eq. (8)) was applied as an objective function to the optimization of operating conditions. Consequently, the optimum parameters were achieved using the numerical technology based on the predicted model and the variable in their critical range. The maximum degradation of $95.01 \%$ was achieved at $\mathrm{pH}=9.9$, $\mathrm{TC}$ concentration = $30.19 \mathrm{mg} / \mathrm{L}$, PS concentration $=3.97 \mathrm{mM}$ and reaction time $=119.98 \mathrm{~min}$. in order to evaluation of the model validity, the experiments were carried out under the optimal operating conditions. $93.45 \%$ TC degradation was obtained under the optimum operating conditions, which supported the results of the developed model.

The perturbation Plot of independent variables implies that reaction time (D) has the most significant effect (steepest slope) on the TC degradation rate, followed by $\mathrm{S}_{2} \mathrm{O}_{8}^{-2}$ concentration (C) and TC concentration (B), whereas $\mathrm{pH}$ (A) has the lowest effect on the TC degradation. (Fig. 5).

\section{Interactive effect of independent variables on the TC degradation}

Three-dimensional surfaces and contour plots are graphical representation of regression equation for the optimization of reaction Status. The results of the interactions between four independent variables and dependent variable are indicated in Figs. 6 and 7.

Figure 6(a) indicates the interaction effect of TC concentration and PS concentration on the TC degradation rate with reaction time of $120 \mathrm{~min}$. with the increasing PS concentration, the TC degradation rate significantly enhanced. With increasing PS concentration from 2 to $4 \mathrm{mM}$, the TC degradation rate increased from $75.56 \%$ to $94.25 \%$ at TC concentration of $30 \mathrm{mg} / \mathrm{L}$. These results suggest that with increasing PS concentration, more sulfate radicals are produced which leads to more quickly TC degradation [32].

Figure 6(b) indicates the interaction effect of initial TC concentration and reaction time on the TC degradation rate. The $\mathrm{TC}$ degradation rate strongly increased with

\begin{tabular}{|c|c|c|c|c|c|c|}
\hline \multirow[t]{2}{*}{ Term } & \multirow[t]{2}{*}{ StdErr** } & \multirow[t]{2}{*}{ VIF } & \multirow[t]{2}{*}{ Ri-Squared } & \multirow{2}{*}{$\begin{array}{l}\text { Power at } 5 \% \\
\mathrm{SN}=0.5\end{array}$} & \multirow{2}{*}{$\begin{array}{l}\text { Power at } 5 \% \\
\mathrm{SN}=1\end{array}$} & \multirow{2}{*}{$\begin{array}{l}\text { Power at } 5 \% \\
\mathrm{SN}=2\end{array}$} \\
\hline & & & & & & \\
\hline A & 0.16 & 1 & 0 & $20.90 \%$ & $63.00 \%$ & $99.50 \%$ \\
\hline B & 0.16 & 1 & 0 & $20.90 \%$ & $63.00 \%$ & $99.50 \%$ \\
\hline C & 0.16 & 1 & 0 & $20.90 \%$ & $63.00 \%$ & $99.50 \%$ \\
\hline D & 0.16 & 1 & 0 & $20.90 \%$ & $63.00 \%$ & $99.50 \%$ \\
\hline$A B$ & 0.2 & 1 & 0 & $15.50 \%$ & $46.50 \%$ & $96.20 \%$ \\
\hline$A C$ & 0.2 & 1 & 0 & $15.50 \%$ & $46.50 \%$ & $96.20 \%$ \\
\hline$A D$ & 0.2 & 1 & 0 & $15.50 \%$ & $46.50 \%$ & $96.20 \%$ \\
\hline$B C$ & 0.2 & 1 & 0 & $15.50 \%$ & $46.50 \%$ & $96.20 \%$ \\
\hline $\mathrm{BD}$ & 0.2 & 1 & 0 & $15.50 \%$ & $46.50 \%$ & $96.20 \%$ \\
\hline$C D$ & 0.2 & 1 & 0 & $15.50 \%$ & $46.50 \%$ & $96.20 \%$ \\
\hline$A^{2}$ & 0.15 & 1.05 & 0.0476 & $68.70 \%$ & $99.80 \%$ & $99.90 \%$ \\
\hline$B^{2}$ & 0.15 & 1.05 & 0.0476 & $68.70 \%$ & $99.980 \%$ & $99.90 \%$ \\
\hline$C^{2}$ & 0.15 & 1.05 & 0.0476 & $68.70 \%$ & $99.80 \%$ & $99.90 \%$ \\
\hline$D^{2}$ & 0.15 & 1.05 & 0.0476 & $68.70 \%$ & $99.80 \%$ & $99.90 \%$ \\
\hline
\end{tabular}
increase of sonication time from 60 to $120 \mathrm{~min}$. with increasing reaction time from 60 to $120 \mathrm{~min}$, TC concentration of 30 and $70 \mathrm{mg} / \mathrm{L}$, the $\mathrm{TC}$ degradation rate

Table 6 The Quadratic model coefficients for the CCD

**Basis Std. Dev. $=1.0$ 

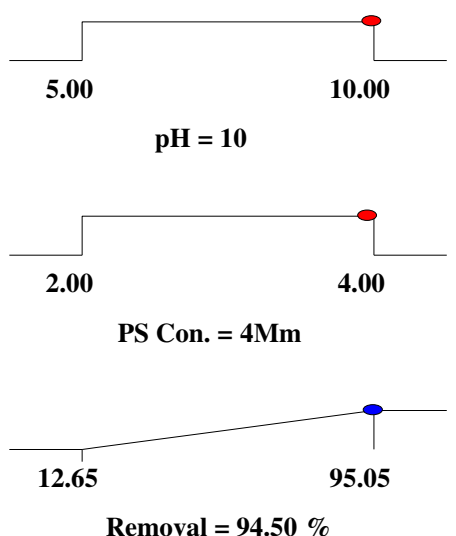

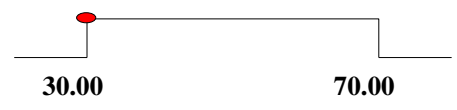

TC Con. $=30.05 \mathrm{mg} / \mathrm{L}$

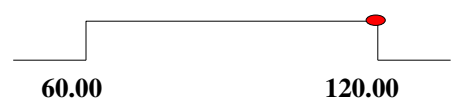

Time $=119.99 \mathrm{~min}$

Desirability $=1.000$

Fig 4 Ramp function graph for the numerical optimization of TC degradation

increased from $70.44 \%$ to $94.25 \%$ at TC concentration of $30 \mathrm{mg} / \mathrm{L}$. With increasing the TC concentration from 30 to $70 \mathrm{mg} / \mathrm{L}$, the $\mathrm{TC}$ degradation rate decreased from $94.25 \%$ to $85.05 \%$. In the constant conditions, with the increasing TC concentration, possibility of reaction between $\mathrm{TC}$ molecules and reactive species were declined. Moreover, the higher concentration of TC may lead to the creation of resistant byproducts and consequently decreases the degradation rate of TC $[14,61]$. However, the total amount of degraded TC increased with the increasing initial TC concentration. This results are in agreement with the results obtained by other researchers [50].

Figure 7 indicates the interaction influence of $\mathrm{pH}$ value and initial TC concentration on the TC degradation rate. With increasing $\mathrm{pH}$ from acidic (5) to natural (7.5), the degradation rate slightly decreased, whereas

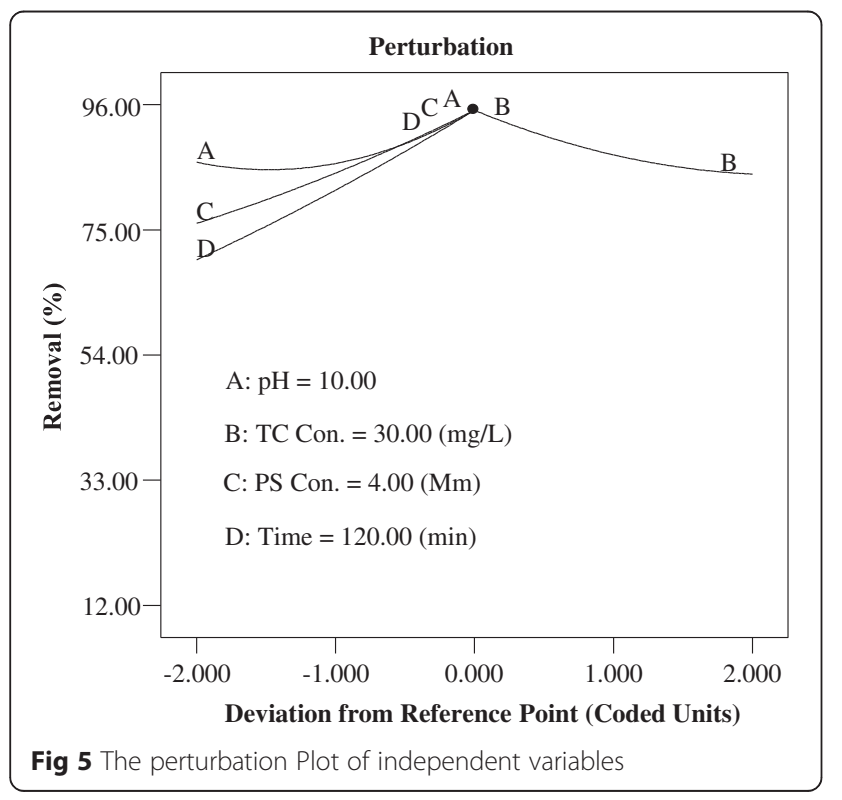

with increasing $\mathrm{pH}$ from neutral (7.5) to alkaline (10), the degradation rate significantly enhanced. The TC degradation rate increased from $86.62 \%$ to $94.25 \%$ with increasing $\mathrm{pH}$ from 5 to 10 , at $\mathrm{TC}$ concentrations of $30 \mathrm{mg} / \mathrm{L}$. Under alkaline conditions $(\mathrm{pH} \geq 10)$, alkalineactivated persulfate is the primary responsible for the production of $\mathrm{SO}_{4}^{-\bullet}, \mathrm{O}_{2}^{-\bullet}$ and $\mathrm{HO}^{*}$ radicals as following equations: [62, 63].

$$
\begin{aligned}
& \mathrm{S}_{2} \mathrm{O}_{8}^{2-}+2 \mathrm{H}_{2} \mathrm{O} \stackrel{\mathrm{OH}^{-}}{\rightarrow} \mathrm{HO}_{2}^{-}+2 \mathrm{SO}_{4}^{2-}+3 \mathrm{H}^{+} \\
& \mathrm{HO}_{2}^{-}+\mathrm{S}_{2} \mathrm{O}_{8}^{2-} \rightarrow \mathrm{SO}_{4}^{-\cdot}+\mathrm{SO}_{4}^{2-}+\mathrm{H}^{+}+\mathrm{O}_{2}^{-\cdot} \\
& \mathrm{SO}_{4}^{-\cdot}+\mathrm{OH}^{-} \rightarrow \mathrm{SO}_{4}^{2-}+\mathrm{HO}^{\cdot}
\end{aligned}
$$

Also, at alkaline $\mathrm{pH}$, sulfate radicals can react with hydroxyl anions to generate hydroxyl radicals ( $\left.\mathrm{HO}^{*}\right)$ according to Eq. (3). In addition, a theory was introduced by other researchers that with increasing $\mathrm{pH}$, the PS degradation into $\mathrm{HO}^{*}$ and $\mathrm{SO}_{4}^{-*}$ increased [64].

The $\mathrm{SO}_{4}^{-*}$ is the predominant radical responsible for TC degradation at acidic $\mathrm{pH}$, whereas both $\mathrm{SO}_{4}^{-*}$ and $\mathrm{OH}^{*}$ are contributing in TC degradation at natural $\mathrm{pH}$. Thus, three reactions compete with each other in natural $\mathrm{pH}$ : the reaction between $\mathrm{SO}_{4}^{-*}$ and $\mathrm{HO}^{*}$, the reaction between $\mathrm{SO}_{4}^{-*}$ and $\mathrm{TC}$, and the reaction between $\mathrm{HO}^{*}$ and $\mathrm{TC}$, the simultaneous occurrence of these reactions may reduce the $\mathrm{TC}$ degradation rate $[37,65]$.

\section{Kinetics of tetracycline degradation}

The sonochemical degradation process typically follows pseudo first-order kinetics as shown in the following Eqs. (13) and (14). Many studies have suggested that oxidation of organic pollutants by ultrasound follows pseudo first-order kinetics [42, 47, 52]. 

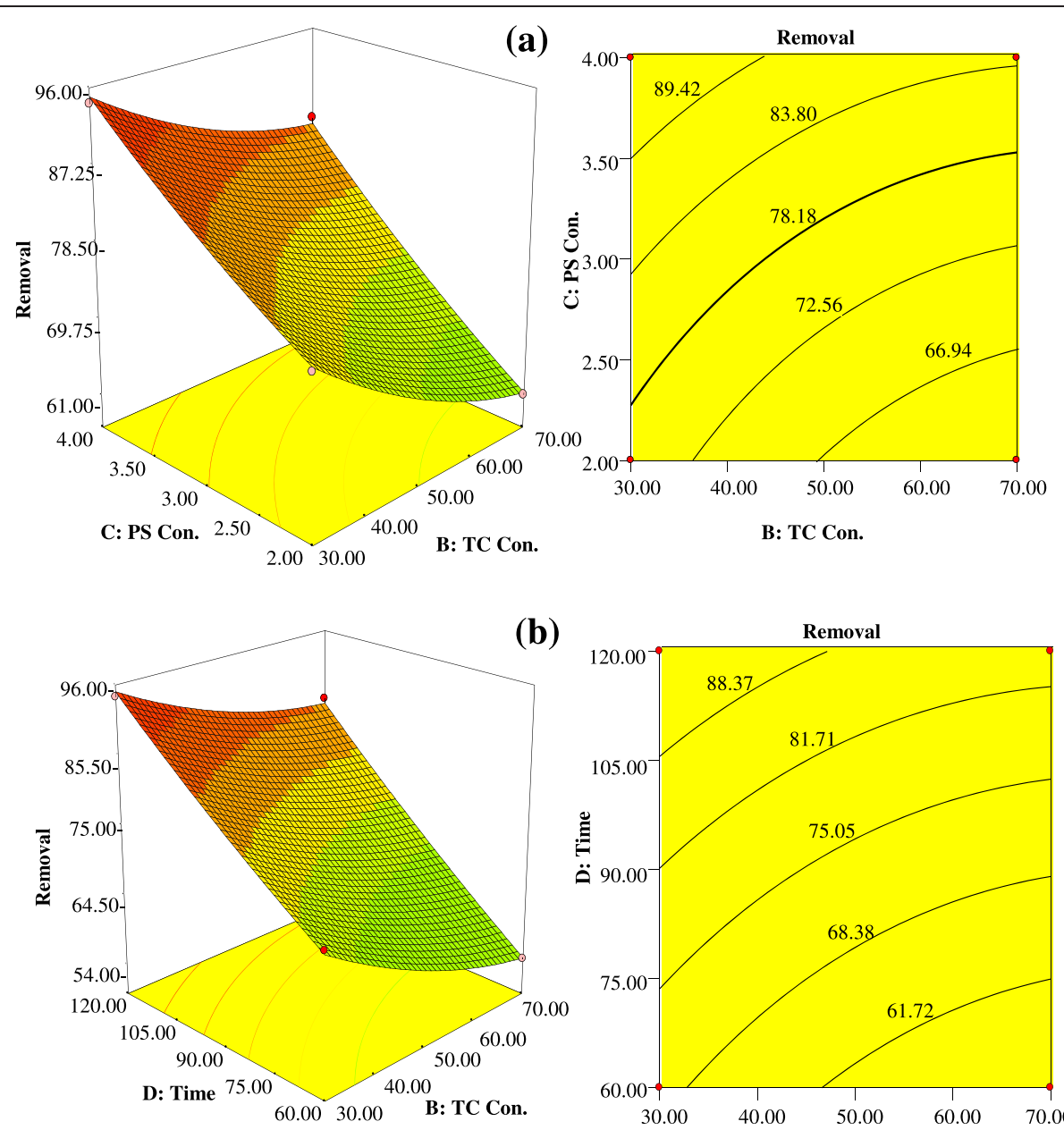

(b)

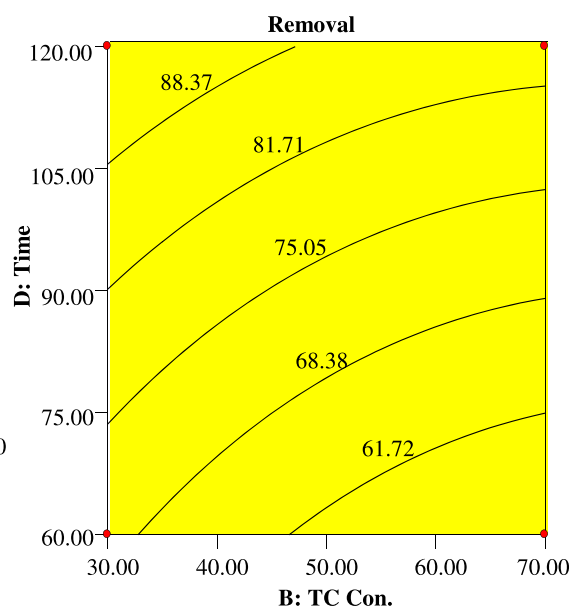

Fig 6 Contour and 3-D plots showing Interactive effect of: (a) TC concentration (mg/L) and PS concentration (mM); (b) TC concentration (mg/L) and sonication time (min)

$$
-\mathrm{d}[\mathrm{TC}] / \mathrm{dt}=\mathrm{k}[\mathrm{TC}]
$$

Eq. (13) can be rewritten as:

$$
\ln \mathrm{Ci} / \mathrm{Ct}=\mathrm{kt}
$$

Where $C_{i}$ is the initial TC concentration, $C_{t}$ is the TC concentration at time $t, k$ is the pseudo first order reaction rate $\mathrm{t}$ is constant $\left(\mathrm{min}^{-1}\right)$ and the reaction time (min). To study the TC degradation by US/ $\mathrm{S}_{2} \mathrm{O}_{8}^{2-}$ process, the data obtained was investigated using the pseudo first order kinetics. The effect of different parameters such as initial TC concentration, initial PS concentration, $\mathrm{pH}$ and temperature on the kinetic of $\mathrm{TC}$ degradation was evaluated. In all the experiments, TC degradation well-fitted to the using the pseudo first order kinetics with higher correlation coefficients $\left(R^{2}\right)$. The values of kinetic rate constants
Table 7 Effect of operation parameters on the kinetics degradation of TC

\begin{tabular}{lllll}
\hline parameter & Value & $k_{0}\left(\mathrm{~min}^{-1}\right) \times 10^{-2}$ & $\mathrm{R}^{2}$ & $\mathrm{t}_{1 / 2}(\mathrm{~min})$ \\
\hline TC concentration $(\mathrm{mg} / \mathrm{L})$ & 25 & 2.29 & 0.9973 & 30.2 \\
& 50 & 1.75 & 0.9952 & 39.6 \\
& 75 & 1.23 & 0.9956 & 56.3 \\
PS concentration $(\mathrm{mM})$ & 2 & 1.15 & 0.9816 & 60.6 \\
& 3 & 1.52 & 0.9946 & 45.9 \\
$\mathrm{pH}$ & 4 & 2.29 & 0.9973 & 30.2 \\
& 5 & 1.62 & 0.9937 & 42.7 \\
& 7.5 & 1.12 & 0.9942 & 62.8 \\
Temperature $\left({ }^{\circ} \mathrm{C}\right)$ & 10 & 2.29 & 0.9973 & 30.2 \\
& 25 & 2.29 & 0.9973 & 30.2 \\
& 45 & 5.70 & 0.9127 & 12.1 \\
& 55 & 7.87 & 0.921 & 8.8 \\
& 65 & 10.42 & 0.9824 & 6.6 \\
\hline
\end{tabular}



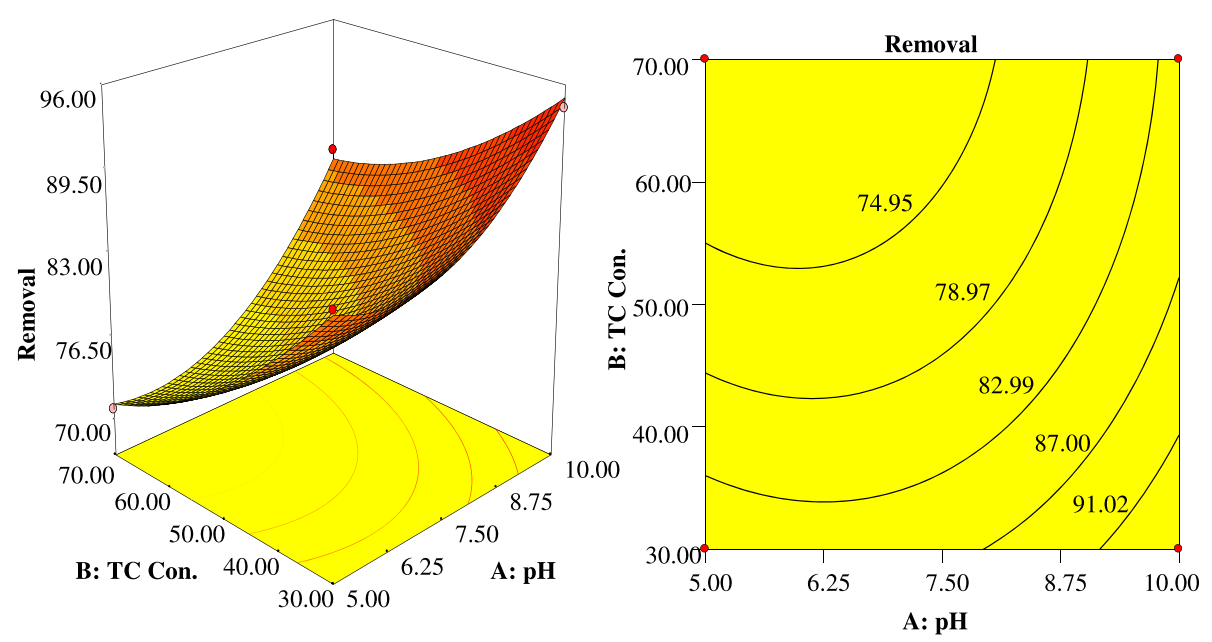

Fig 7 Contour and 3-D plots showing Interactive effect of $\mathrm{pH}$ and TC concentration (mg/L)

(k) related to the different parameters, with their regression coefficients $\mathrm{R}^{2}$ are shown in Table 7 .

\section{The effect of temperature on the degradation of tetracycline}

To investigate the effect of temperature on the TC degradation rate, experiments were done with various temperature varying from 25 to $65{ }^{\circ} \mathrm{C}$. With increasing temperature from 25 to $65{ }^{\circ} \mathrm{C}$, the degradation rate constant increased from 0.0229 to $0.1042 \mathrm{~min}^{-1}$. Complete TC degradation occurs after 40, 60 and 75 min of reaction at 65,55 and $45{ }^{\circ} \mathrm{C}$ respectively. The activation of $\mathrm{S}_{2} \mathrm{O}_{8}^{2-}$ can be done under heat to form $\mathrm{SO}_{4}^{-*}$ radical as following Eq. (15). Therefore, complete removal of TC by high temperature could be as a result of thermally activated
$\mathrm{S}_{2} \mathrm{O}_{8}^{2-}$ oxidation. Moreover, the increase of temperature significantly enhanced the cavitation activity and chemical effects, resulting in greater degradation rate of TC by US/ $\mathrm{S}_{2} \mathrm{O}_{8}^{2-}$ process $[22,60]$.

$$
\mathrm{S}_{2} \mathrm{O}_{8}^{-2}+\stackrel{\text { Termal-activation }}{\rightarrow} 2 \mathrm{SO}_{4}^{-\cdot} \quad\left(30^{\circ} \mathrm{C}<\mathrm{T}<99^{\circ}{ }^{\circ} \mathrm{C}\right)
$$

To investigate the effect of ultrasound on the process kinetics, significant parameters such as activation energy (Ea) play a remarkable role. The effect of temperature on the rate of the reaction and rate constant $(\mathrm{k})$ is obtained by Arrhenius equation according with Eq. (16) [66].

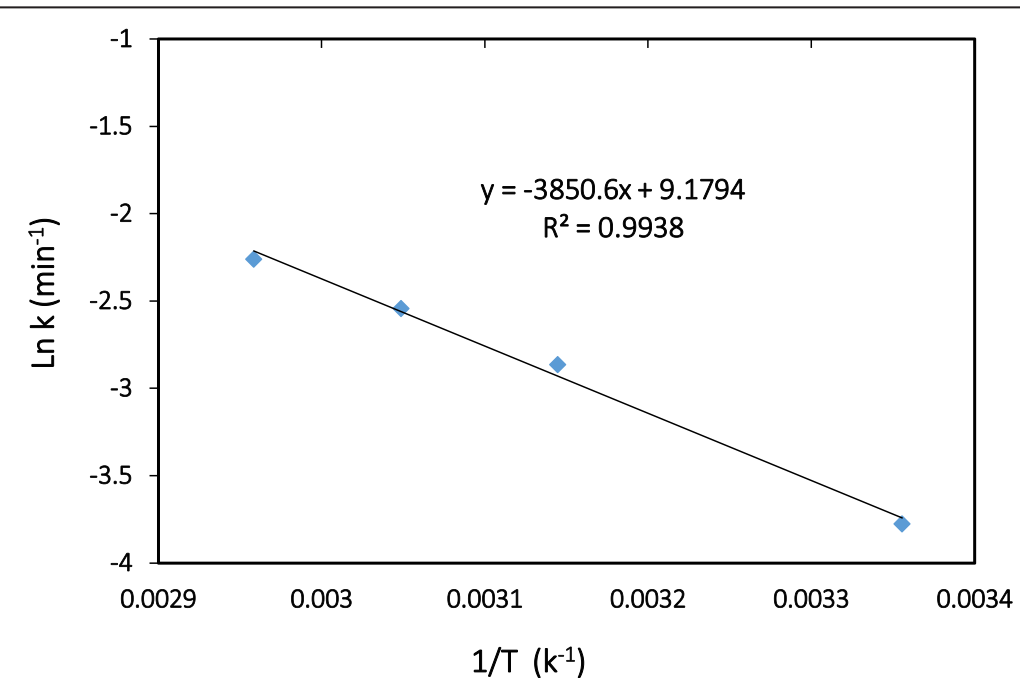

Fig 8 Arrhenius equation graph representation the temperature dependence on chemical reaction rate 


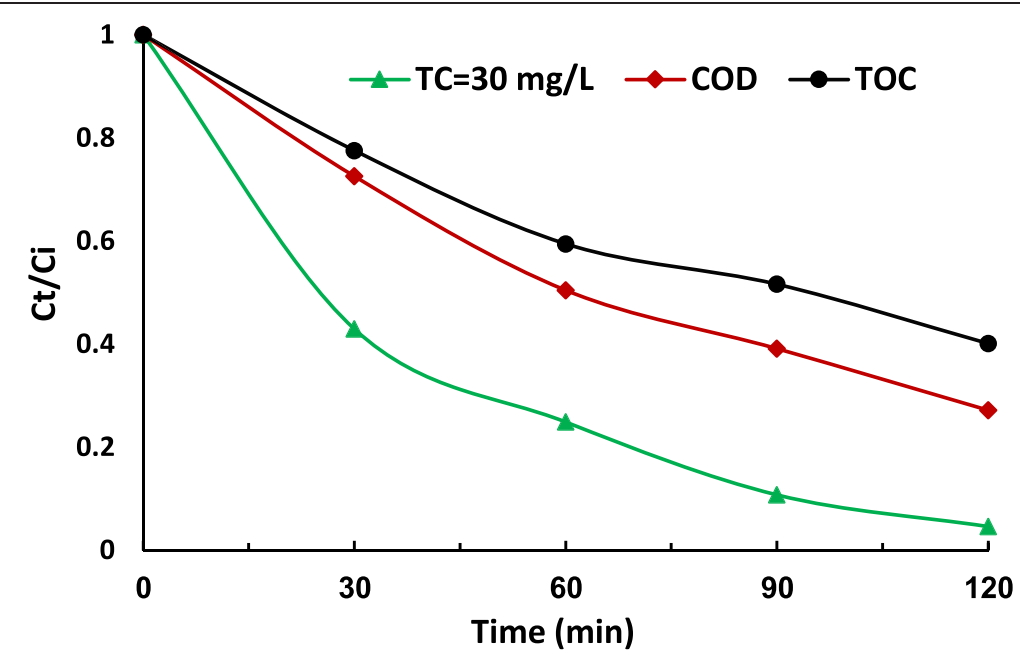

Fig 9 Removal of TC, $\mathrm{COD}$ and TOC by US $/ \mathrm{S}_{2} \mathrm{O}_{8}^{2-}$ process; $\left[\mathrm{S}_{2} \mathrm{O}_{8}^{2-}\right]=4 \mathrm{mM} ; \mathrm{US}: 500 \mathrm{~W}, 35 \mathrm{KHz} ; \mathrm{pH}=10 ; \mathrm{T}=25{ }^{\circ} \mathrm{C}$

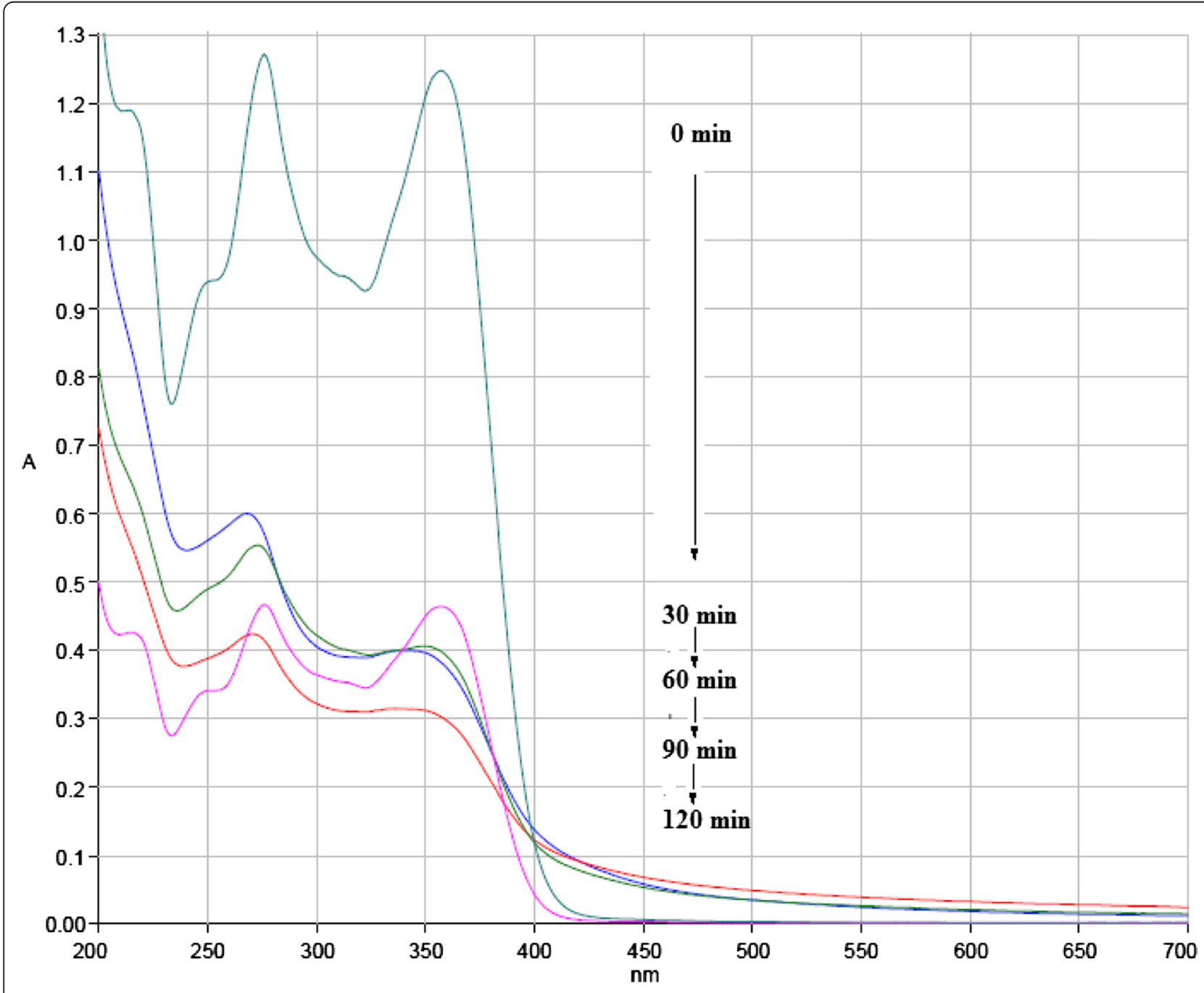

Fig 10 Changes of UV-Vis spectra of $50 \mathrm{mg} / \mathrm{L}$ aqueous solution of TC during process of $\mathrm{US} / \mathrm{S}_{2} \mathrm{O}_{8}^{2-}$ 


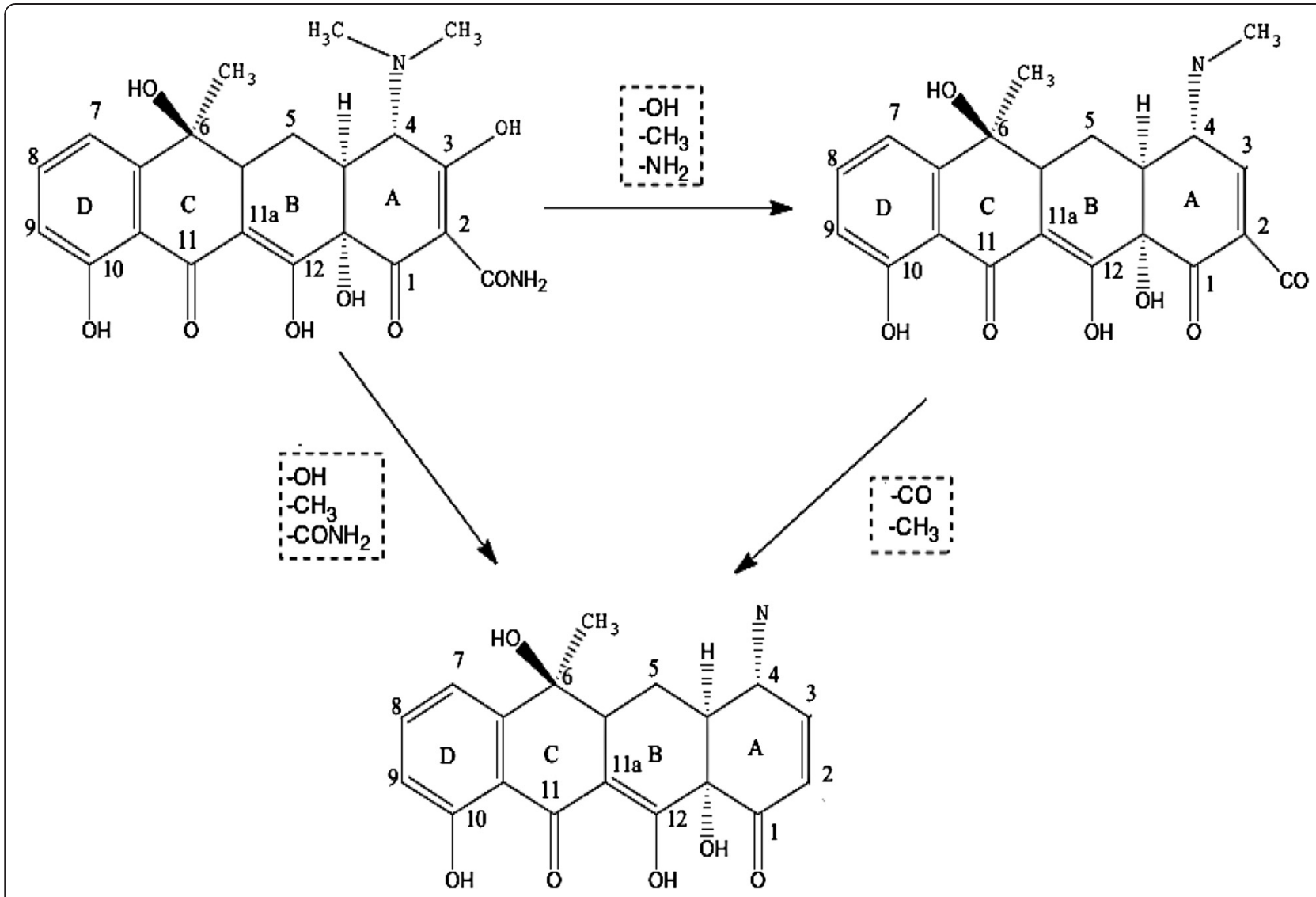

Fig 11 The proposed degradation pathway for tetracycline $\mathrm{S}_{2} \mathrm{O}_{8}^{2-}$

$$
\operatorname{LnK}=\mathrm{A} \exp \left(-\frac{\mathrm{Ea}}{\mathrm{RT}}\right)
$$

Arrhenius plot can be used to calculate the Activation Energy at various temperatures by graphing $\ln \mathrm{k}$ (rate constant) versus $1 / \mathrm{T}$ (kelvin). The graph between ln $\mathrm{k}$ and $1 /$ $\mathrm{T}$ is a straight line with an intercept of $\ln \mathrm{A}$ and the slop of the graph is equal to $-E_{a} / R$, where $R$ is a constant equal to $8.314 \mathrm{~J} / \mathrm{mol}-\mathrm{K}$. According with Arrhenius plot (Fig. 8), the activation energy values of $32.01(\mathrm{~kJ} / \mathrm{mol})$ obtained for degradation of $\mathrm{TC}$ by $\mathrm{S}_{2} \mathrm{O}_{8}^{2-} / \mathrm{US}$ process. It means that for a successful reaction, the colliding molecules must have a total kinetic energy of $32.01 \mathrm{~kJ} / \mathrm{mol}$. The low activation energy indicates that the degradation of $\mathrm{TC}$ by $\mathrm{S}_{2} \mathrm{O}_{8}^{2-} / \mathrm{US}$ process is thermodynamically feasible.

\section{Mineralization, Changes of ultraviolet Visible (UV-Vis)} spectra and the proposed degradation pathway

Usually, sonochemical treatment lead to degradation of structure and ultimately mineralization of organic compounds [67]. While perfect mineralization for most antibiotics are difficult because of the structural stability [68]. Therefore, the changes of TOC and COD were evaluated during $\mathrm{US} / \mathrm{S}_{2} \mathrm{O} 8^{2-}$ process and the result are shown

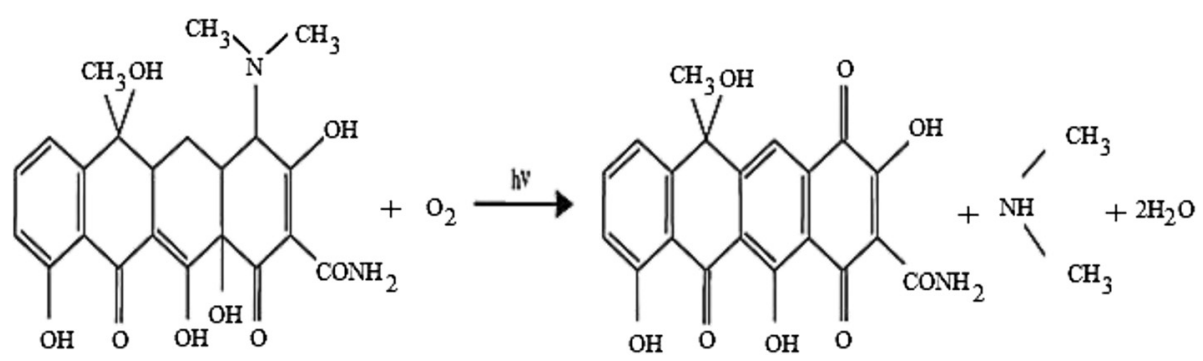

Fig 12 Photodegradation of TC into 4a, 12a-anhydro-4-oxo-4-dedimethylaminotetracycline 
Table 8 Degradation of different types of organic pollutants in aqueous solutions using $U \mathrm{US}_{2} \mathrm{~S}_{2} \mathrm{O}_{8}^{2-}$ process

\begin{tabular}{|c|c|c|c|c|}
\hline compound & $\begin{array}{l}\text { Concentration } \\
(\mathrm{mg} / \mathrm{L})\end{array}$ & operating conditions & Summary of results & reference \\
\hline Tetracycline & 100 & $\begin{array}{l}{\left[\mathrm{S}_{2} \mathrm{O}_{8}^{2-}\right]=200 \mathrm{mM} ; \mathrm{US}=80 \mathrm{~W}, 20 \mathrm{KHz} ;} \\
\mathrm{pH}=3.7 ; \mathrm{T}=\text { ambient }\end{array}$ & More than 51 \% degradation after 120 min. & Hou et al. [48] \\
\hline Trichloroethane & 50 & $\begin{array}{l}{\left[\mathrm{S}_{2} \mathrm{O}_{8}^{2-}\right]=0.94 \mathrm{mM} \cup \mathrm{US}=400 \mathrm{kHz}} \\
100 \mathrm{~W} \mathrm{pH}=7 ; \mathrm{T}=20 \pm 2{ }^{\circ} \mathrm{C}\end{array}$ & $100 \%$ degradation after 120 min. & Li et al. [42] \\
\hline $\begin{array}{l}\text { Perfluorooctanoic } \\
\text { acid }\end{array}$ & 50 & $\begin{array}{l}{\left[\mathrm{S}_{2} \mathrm{O}_{8}^{2-}\right]=46 \mathrm{mM} \text { US }=150 \mathrm{~W}, 40 \mathrm{KHz}} \\
\mathrm{pH}=4.3: \mathrm{T}=25^{\circ} \mathrm{C}\end{array}$ & More than 98 \% degradation after 120 min. & Lin et al. [52] \\
\hline $\begin{array}{l}2,4 \\
\text { Dichlorophenol }\end{array}$ & 50 & $\begin{array}{l}{\left[\mathrm{S}_{2} \mathrm{O}_{8}^{2-}\right]=4 \mathrm{Mm} \cup \mathrm{S}=40 \mathrm{KHz}, \mathrm{pH}=3 ;} \\
\mathrm{T}=30^{\circ} \mathrm{C}\end{array}$ & More than $95 \%$ degradation after 60 min. & $\begin{array}{l}\text { Seid } \\
\text { Mohammai } \\
{[74]}\end{array}$ \\
\hline Acid Orange 7 & 30 & $\begin{array}{l}{\left[\mathrm{S}_{2} \mathrm{O}_{8}^{2-}\right]=1.25 \mathrm{Mm} \text { US }=100 \mathrm{~W}, 20 \mathrm{kHz}} \\
\mathrm{pH}=5.8 ; \mathrm{T}=\text { ambient }\end{array}$ & More than $10 \%$ degradation after 20 min. & $\begin{array}{l}\text { Wang et al. } \\
{[75]}\end{array}$ \\
\hline Tetracycline & 30 & $\begin{array}{l}{\left[\mathrm{S}_{2} \mathrm{O}_{8}^{2-}\right]=4 \mathrm{Mm} \text { US }=500 \mathrm{~W}, 35 \mathrm{KHz}} \\
\mathrm{pH}=10 ; \mathrm{T}=25 \pm 2{ }^{\circ} \mathrm{C}\end{array}$ & $\begin{array}{l}\text { More than } 95 \% \text { degradation, COD and TOC removal of } \\
72 \% \text { and } 59 \% \text { after } 120 \text { min }\end{array}$ & Present study \\
\hline
\end{tabular}

in Fig. 9. After 120 min of reaction, TC, COD and TOC were removed approximate $95 \%, 73 \%$ and $60 \%$. The incomplete mineralization implies the potential formation of intermediate products and further identification of the degradation by-products is required.

To evaluate structural changes of TC, the UV-Vis spectra obtained before and after US/ $\mathrm{S}_{2} \mathrm{O}_{8}^{2-}$ process in various time are shown in Fig. 10. The UV-Vis spectra obtained before process indicates two main absorption bands at 275 and $360 \mathrm{~nm}$. The absorption of TC in $360 \mathrm{~nm}$ is due to aromatic rings $\mathrm{B}-\mathrm{D}$, such as the developed chromophores $[68,69]$. With increase of reaction time, the absorption band slightly decreased because of the fragmentation of phenolic groups attached to aromatic ring $B$ $[69,70]$. The generation of acylamino and hydroxyl groups led to reduction of absorbance at $270 \mathrm{~nm}$ band [70]. The absorption decay at $360 \mathrm{~nm}$ band faster than $275 \mathrm{~nm}$. This implies that the ring containing the $\mathrm{N}$-groups (responsible for the absorbance at $276 \mathrm{~nm}$ ) hardly opened than the other rings, or the created intermediate products absorbed at this wavelength [71]. The proposed degradation pathway for tetracycline based on loses of N-methyl, hydroxyl, and amino groups is shown in Fig. 11. This possible pathway corresponded with conducted studies by other researchers [72]. In addition, $\mathrm{TC}$ has a naphthol ring with high stability, which remains unchanged in the reaction and is not easily mineralized. Also, the absorption decay at $360 \mathrm{~nm}$ band was found with a relatively small absorption in the visible region. This could be due to the forming of 4a,12a-anhydro-4-oxo-4-dedimethylaminotetracycline according to Fig. 12 [73].

\section{Performance evaluation of $\mathrm{US} / \mathrm{S}_{2} \mathrm{O}_{8}^{2-}$ process in the removal of different organics}

An overview of performance of $\mathrm{US} / \mathrm{S}_{2} \mathrm{O}_{8}^{2-}$ process for removal of different organics along with present study was presented in Table 8. The overview confirm that US/ $\mathrm{S}_{2} \mathrm{O}_{8}^{2-}$ process is an attractive alternative technique for degradation of the wide range of organic compounds in aqueous solutions. This process could effectively decomposed organic pollutants in aqueous solution, and the degradation rate depends heavily on the operating conditions, such as physical and chemical characteristics and initial concentration of pollutant, $\mathrm{S}_{2} \mathrm{O}_{8}^{2-}$ concentration, initial $\mathrm{pH}$, reaction time, ultrasound power, ultrasound frequency, and temperature of the medium. Therefore, the various experimental conditions could lead to the various removal efficiencies of organic compounds using $\mathrm{US} / \mathrm{S}_{2} \mathrm{O}_{8}^{2-}$ process.

\section{Conclusion}

Sonochemical degradation of $\mathrm{TC}$ in the presence of $\mathrm{S}_{2} \mathrm{O}_{8}^{2-}$ was investigated with focusing on the optimizing of the operation parameters such as $\mathrm{pH}, \mathrm{S}_{2} \mathrm{O}_{8}^{2-}$ concentration, initial TC concentration and reaction time. This study indicated that RSM was the suitable method to optimizing the best operating conditions to maximizing the TC degradation. The reaction time showed the highest effect on the TC degradation, followed by initial $\mathrm{S}_{2} \mathrm{O}_{8}^{2}$ - concentration, initial TC concentration and $\mathrm{pH}$. Under optimal conditions, the TC degradation rate, COD and TOC removal efficiency were found to be $95.01 \%$, $72.8 \%$ and $59.7 \%$, respectively. The degradation process followed the pseudo-first-order kinetics. The activation energy value of $31.71 \mathrm{~kJ} / \mathrm{mol}$ implies that the degradation of $\mathrm{TC}$ by $\mathrm{US} / \mathrm{S}_{2} \mathrm{O}_{8}^{2-}$ process is thermodynamically feasible. The ultraviolet visible spectra obtained before and after ultrasound irradiation in the presence of $\mathrm{S}_{2} \mathrm{O}_{8}^{2-}$ indicated that proposed degradation pathway for tetracycline was based on loses of N-methyl, hydroxyl, and amino groups. Overall, $\mathrm{US} / \mathrm{S}_{2} \mathrm{O}_{8}^{2-}$ process was found to be a promising technology for $\mathrm{TC}$ degradation in aqueous solution.

\section{Competing interests}

The authors declare that they no competing interests. 


\section{Authors' contributions}

GHS was the main investigator, collected the data, performed the statistical analysis, and drafted the manuscript. SN and AHM supervised the study and participated in the design of the study, final revised of manuscript and intellectual helping for analyzing of data. KY, RN, and MA were advisors of the study and carried out statistical and technical analysis of data, participated in design of study and manuscript preparation. All authors read and approved the final manuscript.

\section{Acknowledgments}

This research was part of a PhD dissertation of the first author and has been supported by Tehran University of Medical Sciences under grant no. 92-03-4624084. The authors express their gratitude to all laboratory staff of the Department of Environmental Health Engineering.

\section{Author details}

${ }^{1}$ Department of Environmental Health Engineering, School of Public Health, Tehran University of Medical Sciences, Tehran, Iran. ${ }^{2}$ Center for Water Quality Research, Institute for Environmental Research, Tehran University of Medical Sciences, Tehran, Iran. ${ }^{3}$ Center for Solid Waste Research, Institute for Environmental Research, Tehran University of Medical Sciences, Tehran, Iran. ${ }^{4}$ Center for Air Pollution Research, Institute for Environmental Research, Tehran University of Medical Sciences, Tehran, Iran.

Received: 30 May 2015 Accepted: 19 October 2015 Published online: 04 November 2015

\section{References}

1. Javid A, Nasseri S, Mesdaghinia A, Mahvi AH, Alimohammadi M, Aghdam $\mathrm{RM}$, et al. Performance of photocatalytic oxidation of tetracycline in aqueous solution by $\mathrm{TiO}_{2}$ nanofibers. J Environ Health Sci Eng. 2013;11:24.

2. Daghrir $R$, Drogui $P$. Tetracycline antibiotics in the environment: a review. Environ Chem Lett. 2013;11:209-27.

3. Jiang WT, Chang PH, Wang YS, Tsai Y, Jean JS, Li Z. Sorption and desorption of tetracycline on layered manganese dioxide birnessite. Int J Environ Sci Technol. 2015;12:1695-704.

4. Lindsey ME, Meyer M, Thurman E. Analysis of trace levels of sulfonamide and tetracycline antimicrobials in groundwater and surface water using solid-phase extraction and liquid chromatography mass spectrometry. Anal Chem. 2001;73:4640-6.

5. Alavi N, Babaei AA, Shirmardi M, Naimabadi A, Goudarzi G. Assessment of oxytetracycline and tetracycline antibiotics in manure samples in different cities of Khuzestan Province. Iran Environ Sci Pollut Res. 2015;1-7.

6. Zhu J, Snow DD, Cassada DA, Monson SJ, Spalding RF. Analysis of oxytetracycline, tetracycline and chlortetracycline in water using solid-phase extraction and liquid chromatography-tandem mass spectrometry. J Chromatogr A. 2001;928:177-86.

7. Guler UA, Sarioglu M. Removal of tetracycline from wastewater using pumice stone: equilibrium, kinetic and thermodynamic studies. J Environ Health Sci Eng. 2014;12:1.

8. Reyes C, Fernandez J, Freer J, Mondaca MA, Zaror C, Malato S, et al. Degradation and inactivation of tetracycline by $\mathrm{TiO}_{2}$ photocatalysis. J Photochem Photobiol A. 2006;184:141-6.

9. Spongberg AL, Witter JD. Pharmaceutical compounds in the wastewater process stream in Northwest Ohio. Sci total environ. 2008;397:148-57.

10. Karthikeyan KG, Michael TM. Occurrence of antibiotics in wastewater treatment facilities in Wisconsin, USA. Sci total environ. 2006;361:196-207.

11. Deblonde T, Cossu-Leguille C, Hartemann P. Emerging pollutants in wastewater: a review of the literature. Int J Hyg Environ Eealth. 2011;214:442-8.

12. Homem $V$, Santos $L$. Degradation and removal methods of antibiotics from aqueous matrices-a review. J Environ Manag. 2011;92:2304-47.

13. Choi KJ, Kim SG, Kim SH. Removal of antibiotics by coagulation and granular activated carbon filtration. J Hazard Mater. 2008;151:38-43.

14. Safari GH, Hoseini M, Seyedsalehi M, Kamani H, Jaafari J, Mahvi AH. Photocatalytic degradation of tetracycline using nanosized titanium dioxide in aqueous solution. Int J Environ Sci Technol. 2014;12:603-16.

15. Kakavandi B, Takdastan A, Jaafarzadeh N, Azizi M, Mirzaei A, Azari A. Application of $\mathrm{Fe}_{3} \mathrm{O}_{4} @ \mathrm{C}$ catalyzing heterogeneous UV-Fenton system for tetracycline removal with a focus on optimization by a response surface method. J Photochem Photobio A Chem. 2015;2016(314):178-88.
16. Tsitonaki A, Petri B, Crimi M, Mosbaek H, Siegrist RL, Bjerg PL. In situ chemical oxidation of contaminated soil and groundwater using persulfate: a review. Crit Rev Environ Sci Technol. 2010;40:55-91.

17. Li SX, Wei D, Mak NK, Cai ZW, Xu XR, Li HB, et al. Degradation of diphenylamine by persulfate: performance optimization, kinetics and mechanism. J Hazard Mater. 2009;164:26-31.

18. Adewuyi YG, Owusu SO. Ultrasound-induced aqueous removal of nitric oxide from flue gases: effects of sulfur dioxide, chloride, and chemical oxidant. J Phys Chem A. 2006;110:11098-107.

19. Weng $\mathrm{CH}$, Tao $\mathrm{H}$. Highly efficient persulfate oxidation process activated with $\mathrm{Fe}^{0}$ aggregate for decolorization of reactive azo dye Remazol Golden Yellow. Arabian J Chem. 2015; doi.org/10.1016/j.arabjc.2015.05.012.

20. Fang JY, Shang C. Bromate formation from bromide oxidation by the UV/ persulfate process. Environ Sci Technol. 2012;46:8976-83.

21. Johnson RL, Tratnyek PG, Johnson ROB. Persulfate persistence under thermal activation conditions. Environ Sci Technol. 2008;42:9350-6.

22. Mora VC, Rosso JA, Le C, Roux G, Roux GC, Martire DO, et al. Thermally activated peroxydisulfate in the presence of additives: a clean method for the degradation of pollutants. Chemosphere. 2009;75:1405-9.

23. Asgari G, Seidmohammadi AM, Chavoshani A. Pentachlorophenol removal from aqueous solutions by microwave/persulfate and microwave $/ \mathrm{H}_{2} \mathrm{O}_{2}$ : a comparative kinetic study. J Environ Health Sci Eng. 2014;12:94.

24. Chen WS, Su YC. Removal of dinitrotoluenes in wastewater by sonoactivated persulfate. Ultrason Sonochem. 2012;19:921-7.

25. Furman OS, Teel AL, Watts RJ. Mechanism of base activation of persulfate. Environ Sci Technol. 2010;44:6423-8.

26. Yang S, Yang X, Shao X, Niu R, Wang L. Activated carbon catalyzed persulfate oxidation of azo dye acid orange 7 at ambient temperature. J Hazard Mater. 2011;86:659-66.

27. Fang G, Gao J, Dionysiou DD, Liu C, Zhou D. Activation of persulfate by quinones: Free radical reactions and implication for the degradation of PCBs. Environ Sci Technol. 2013;47:4605-11.

28. Liang $\mathrm{C}$, Liang $\mathrm{CP}$, Chen CC. $\mathrm{pH}$ dependence of persulfate activation by EDTA/Fe (III) for degradation of trichloroethylene. J Contam Hydrol. 2009;106:173-82.

29. Liang C, Guo Y, Chien Y, Wu Y. Oxidative degradation of MTBE by pyrite-activated persulfate: proposed reaction kinetics. J Contam Hydrol. 2010:49:8858-64.

30. Criquet J, Leitmer NKV. Electron beam irradiation of aqueous solution of persulfate ions. Chem Eng J. 2011;169:258-62.

31. Ahmad M, Teel AL, Watts RJ. Mechanism of persulfate activation by phenols. Environ Sci Technol. 2013;47:5864-71.

32. Xu XR, Li XZ. Degradation of azo dye Orange $G$ in aqueous solutions by persulfate with ferrous ion. Sep Purif Technol. 2010;72:105-11.

33. Rivas FJ. Polycyclic aromatic hydrocarbons sorbed on soils: a short review of chemical oxidation based treatments. J Hazard Mater. 2006;138:234-51.

34. Anipsitakis GP, Dionysiou DD. Radical generation by the interaction of transition metals with common oxidants. Environ Sci Technol. 2004;38:3705-12.

35. Zhao J, Zhang Y, Quan X, Chen S. Enhanced oxidation of 4-chlorophenol using sulfate radicals generated from zero-valent iron and peroxydisulfate at ambient temperature. Sep Purif Technol. 2010;71:302-7.

36. Antoniou MG, Cruz AA, Dionysiou DD. Degradation of microcystin-LR using sulfate radicals generated through photolysis, thermolysis and e- transfer mechanisms. Appl Catal B Environ. 2010;96:290-8.

37. Lin YT, Liang CJ, Chen GH. Feasibility study of ultraviolet activated persulfate oxidation of phenol. Chemosphere. 2011:82:1168-72.

38. Liang HY, Zhang YQ, Huang SB, Hussain I. Oxidative degradation of $\mathrm{p}$ chloroaniline by copper oxidate activated persulfate. Chem Eng J. 2013;218:384-91.

39. Olmez-Hanci T, Arslan-Alaton I. Comparison of sulfate and hydroxyl radical based advanced oxidation of phenol. Chem Eng J. 2013;224:469-74.

40. Ji Y, Dong C, Kong D, Lu J, Zhou Q. Heat-activated persulfate oxidation of atrazine: Implications for remediation of groundwater contaminated by herbicides. Chem Eng J. 2015;263:45-54.

41. Zhou D, Chen L, Zhang C, Yu Y, Zhang L. novel photochemical system of ferrous sulfite complex: Kinetics and mechanisms of rapid decolorization of Acid Orange 7 in aqueous solutions. Water Res. 2014;57:85-97.

42. Li B, Li L, Lin K, Zhang W, Lu S, Luo Q. Removal of 1,1,1-trichloroethane from aqueous solution by a sono-activated persulfate process. Ultrason Sonochem. 2013;20:855-63. 
43. Sivakumar R, Muthukumar K. Sonochemical degradation of pharmaceutical wastewater. Clean Soil Air Water. 2011;39:136-41.

44. Neppolian B, Doronila A, Ashokkumar M. Sonochemical oxidation of arsenic (III) to arsenic (V) using potassium peroxydisulfate as an oxidizing agent. Water Res. 2010;44:3687-95.

45. Neppolian B, Jung $H$, Choi H, Lee JH, Kang JW. Sonolytic degradation of methyl tert-butyl ether: the role of coupled Fenton process and persulphate ion. Water Res. 2002:36:4699-708.

46. Son HS, Choi SB, Khan E, Zoh KD. Removal of 1, 4-dioxane from water using sonication: effect of adding oxidants on the degradation kinetics. Water Res. 2006;:40:692-8

47. Su S, Guo W, Yi C, Leng Y, Ma Z. Degradation of amoxicillin in aqueous solution using sulphate radicals under ultrasound irrdidation. Ultrason Sonochem. 2012;19:469-74.

48. Hou L, Zhang H, Xue X. Ultrasound enhanced heterogeneous activation of peroxydisulfate by magnetite catalyst for the degradation of tetracycline in water. Sep Purif Technol. 2012;84:147-52.

49. Gayathri P, Dorathi RPJ, Palanivelu K. Sonochemical degradation of textile dyes in aqueous solution using sulphate radicals activated by immobilized cobalt ions. Ultrason Sonochem. 2010;17:566-71.

50. Kwon M, Kim S, Yoon Y, Jung Y, Hwang TM, Lee J, et al. Comparative evaluation of ibuprofen removal by $U \mathrm{UV}_{2} \mathrm{H}_{2} \mathrm{O}_{2}$ and $\mathrm{UV} / \mathrm{S}_{2} \mathrm{O}_{8}^{2-}$ processes for wastewater treatment. Chem Eng J. 2015:269:379-90.

51. Chen WS, Huang YL. Removal of dinitrotoluenes and trinitrotoluene from industrial wastewater by ultrasound enhanced with titanium dioxide. Ultrason sonochem. 2011;18:1232-40.

52. Lin JC, Lo SL, Hu CY, Lee YC, Kuo J. Enhanced sonochemical degradation of perfluorooctanoic acid by sulfate ions. Ultrason Sonochem. 2014;22:542-7.

53. Ghafoori S, Mowla A, Jahani R, Mehrvar M, Chan PK. Sonophotolytic degradation of synthetic pharmaceutical wastewater: Statistical experimental design and modeling. J Environ Manage. 2015;150:128-37.

54. Rezaee R, Maleki A, Jafari A, Mazloomi S, Zandsalimi Y, Mahvi AH. Application of response surface methodology for optimization of natural organic matter degradation by $\mathrm{UV} / \mathrm{H}_{2} \mathrm{O}_{2}$ advanced oxidation process. J Environ Health Sci Eng. 2014;12:1.

55. Montgomery DC. Design and Analysis of Experiments. 6th ed. New York: John Wiley \& Sons; 2005

56. Affam AC, Chaudhuri M. Optimization of Fenton treatment of amoxicillin and cloxacillin antibiotic aqueous solution. Desal Water Treat. 2014:52:1878-84

57. Zuorro A, Fidaleo M, Fidaleo M, Lavecchia R. Degradation and antibiotic activity reduction of chloramphenicol in aqueous solution by $\mathrm{UV} / \mathrm{H}_{2} \mathrm{O}_{2}$ process. J Environ Manage. 2014;133:302-8.

58. Morshedi A, Akbarian M. Application of response surface methodology: design of experiments and optimization: a mini review. In J Fund Appl Life Sci. 2014:54:2434-9.

59. Domınguez JR, Munoz MJ, Palo P, Gonzalez T, Peres JA, Cuerda-Correa EM. Fenton advanced oxidation of emerging pollutants: parabens. Int J Energy Environ Eng. 2014:5:1-10.

60. Xu M, Du H, Gu X, Lu S, Qiu Z, Sui Q. Generation and intensity of active oxygen species in thermally activated persulfate systems for the degradation of trichloroethylene. RSC Advances. 2014;76:40511-7.

61. Hoseini M, Safari GH, Kamani H, Jaafari J, Ghanbarain M, Mahvi AH. Sonocatalytic degradation of tetracycline antibiotic in aqueous solution by sonocatalysis. Toxicol Environ Chem. 2014;95:1680-9.

62. Saeed $W$. The effectiveness of persulfate in the oxidation of petroleum contaminants in saline environment at elevated groundwater temperature. Ontario, Canada: Waterloo; 2011.

63. Zhao D, Liao X, Xiulan Y, Huling SG, Chai T, Huan T. Effect and mechanism of persulfate activated by different methods for PAHs removal in Soi. J Hazard Mater. 2013:254:228-35.

64. Guan YH, Ma J, Li XC, Fang JY, Chen LW. Effect of pH on the formation of sulfate and hydroxyl radicals in the UV/peroxymonosulfate system. Environ Sci Technol. 2011;45:9308-14.

65. Liang C, Su HW. Identification of sulfate and hydroxyl radicals in thermally activated persulfate. Ind Eng Chem Res. 2009;48:5558-62.

66. Ji YF, Ferronato C, Salvador A, Yang X, Chovelon JM. Degradation of ciprofloxacin and sulfamethoxazole by ferrous-activated persulfate: Implications for remediation of groundwater contaminated by antibiotics. Sci Total Environ. 2014:472:800-8 [38].
67. Jiao $S$, Zheng $S$, Yin $D$, Wang $L$, Chen $L$. Aqueous photolysis of tetracycline and toxicity of photolytic products to luminescent bacteria. Chemosphere. 2008;73:377-82.

68. Shaojun JIAO, Zheng S, Daqiang YIN, Lianhong WANG, Liangyan CHEN. Aqueous oxytetracycline degradation and the toxicity change of degradation compounds in photoirradiation process. J Environ Sci. 2008:20:806-13.

69. Wang Y, Zhang H, Zhang J, Lu C, Huang Q, Wu J, et al. Degradation of tetracycline in aqueous media by ozonation in an internal loop-lift reactor. J Hazard Mater. 2011;192:35-43.

70. Zhu XD, Wang YJ, Sun RJ, Zhou DM. Photocatalytic degradation of tetracycline in aqueous solution by nanosized $\mathrm{TiO}_{2}$. Chemosphere. 2013:92:925-32.

71. Dalmazio I, Almeida MO, Augusti R. Monitoring the degradation of tetracycline by ozone in aqueous medium via atmospheric pressure ionization mass spectrometry. J Am Soc Mass Spectrom. 2007;18:679-87.

72. Ma Y, Gao N, Li C. Degradation and pathway of tetracycline hydrochloride in aqueous solution by potassium ferrate. Environ Eng Sci. 2012;29:357-62.

73. Addamo M, Augugliaro V, Di Paola A, Garcia-Lopez E, Loddo V, Marci G, et al. Removal of drugs in aqueous systems by photoassisted degradation. J Appl Electrochem. 2005;35:765-74.

74. Seid Mohammadi A, Asgari G, Almasi H. Removal of 2,4 Di-Chlorophenol Using Persulfate Activated with Ultrasound from Aqueous Solutions. J Environ Eng. 2014:4:260-68

75. Wang X, Wang L, Li J, Qiu J, Cai C, Zhang H. Degradation of Acid Orange 7 by persulfate activated with zero valent iron in the presence of ultrasonic irradiation. Sep Pur Technol. 2014;122:41-46.

\section{Submit your next manuscript to BioMed Central and take full advantage of:}

- Convenient online submission

- Thorough peer review

- No space constraints or color figure charges

- Immediate publication on acceptance

- Inclusion in PubMed, CAS, Scopus and Google Scholar

- Research which is freely available for redistribution 